\title{
REACTIONS OF O-AMINO-N-(1,1-DIMETHYLPROP-2-YNYL)-BENZAMIDE
}

\author{
C.O. Usifoh and L. Okunrobo \\ Department of Pharmaceutical Chemistry, Faculty of Pharmacy, \\ University of Benin, Benin City, Nigeria.
}

\begin{abstract}
Carbonylation of o-amino-N-(1,1-dimethylprop-2-ynyl)-benzamide 3 with ethyl chloroformate gave 2-carbethoxyamino- $N$-(1,1-dimethylprop-2-ynyl)-benzamide 6. Attempted cyclization of 6 under basic conditions did not give the quinazoline 8 but an oxazole 7. When $\mathbf{3}$ was also refluxed in triethylorthoformate-acetic anhydride mixture, 2-acetylamino- $N$-(1,1-dimethylprop2-ynyl)-benza-mide 4 was formed as the major compound with negligible amount of 3-(1,1dimethylprop-2-ynyl)-quinazolin-4-(3H)-one 5.
\end{abstract}

\section{INTRODUCTION}

The synthesis and biological activities of 3-substituted quinazolinones are well documented ${ }^{1,3,5}$. The carbonylation of the benzamide 3 and other related amides using bis(trichloromethyl)-carbonate (triphosgene), a substitute for phosgene, have been carried out ${ }^{5,6}$. A search for possible alternative route for the quinazolinone $\mathbf{8}$ and the avoidance of the probable harzadous effect of phosgene prompted the attempted cyclization to the quinazolinone 8 reported in this paper. Acetic anhydride instead of glacial acetic acid has been ultilised in the synthesis of $\mathbf{5}$ and an $\mathrm{N}$ acetylated derivative was reported but not characterised ${ }^{7}$. Isatoic anhydride is useful in the synthesis of heterocyclic compounds ${ }^{8}$. The condensation of isatoic anhydride with primary or secondary amines gives rise to substituted anthranilamides. Benzamides like o-amino-N-(1,1dimethylprop-2-ynyl)-benzamide and 2-carbethoxyamino$\mathrm{N}$-(1,1-dimethylprop-2-ynyl)-benzamide could be biologically useful, since related amides have been employed as potential muscle relaxant and anticonvulsant ${ }^{9}$. Acetylenic amines have been used in the synthesis of potential biologically active heterocyclic compounds. Recently the anticonvulsant activity of some acetylenic quinazolinone derivatives have been evaluated and most of them exhibited significant activity in the seizure threshold test with subcutaneous pentylenetetrazole (ScMet test) and in the maximal electroschock test (MES test $)^{10}$. The cyclisation of $\mathrm{N}$ - propynyl amides to oxazoles have been executed with acid and metallic catalysts.However base induced ring closures are not frequently encountered ${ }^{5 \ldots}$

\section{EXPERIMENTAL}

Melting points were determined on a Kofler hot stage apparatus and were uncorrected. The ${ }^{1} \mathrm{H}$ and ${ }^{13} \mathrm{C} \mathrm{nmr} \mathrm{spectra}$ were recorded in appropriate solvent at $200 \mathrm{MHz}$ and 50 $\mathrm{MHz}$ respectively with tetramethylsilane as internal reference on a Bruker WM 300 spectrometer. Mass spectra were obtained on a Varian MAT 44S Instrument at $70 \mathrm{ev}$. The ir spectra were recorded on a Pye Unicam SP3-200 ir spectrophotometer. Silica gel $60 \mathrm{~F}_{254}$ (precoated aluminium sheets, $0.2 \mathrm{~mm}$ thickness; Merck 5549) were used for analytical tlc.

\section{o-Amino-N-(1,1-dimethylprop-2-ynyl)-benzamide 3}

1,1-Dimethylprop-2-ynylamine $2.49 \mathrm{~g}(0.03 \mathrm{~mol})$ was added to isatoic anhydride $3.26 \mathrm{~g}(0.02 \mathrm{~mol})$ in $20 \mathrm{ml} \mathrm{DMF}$ dropwisely over a period of 30 minutes. The reaction mixture was maintained at $50^{\circ} \mathrm{C}$ for 4 hours until tlc indicated disappearance of isatoic anhydride. The reaction mixture was poured into $200 \mathrm{ml}$ of water and adjusted to $\mathrm{pH} 9$ with $50 \% \mathrm{NaOH}$. The solid precipitate obtained was filtered, washed free of base with $3 \times 20 \mathrm{ml}$ portions of water, dried and purified through column chromatography (dichloromethane). Recrystallisation from dichloromethanepetroleum ether $\left(30-40^{\circ} \mathrm{C}\right)$ gave colourless needles; $2.62 \mathrm{~g}$ (65\%) mp. 121-122 ${ }^{\circ} \mathrm{C}\left[\mathrm{Litt}^{5} ; 121-123^{\circ} \mathrm{C}\right]$. IR (KBr): 3490, 3400, $3390\left(\mathrm{NH}_{2}, \mathrm{NH}\right), 3000,1645(\mathrm{C}=\mathrm{O}), 1600,1260,760,700 \mathrm{~cm}^{-1}$. ${ }^{1} \mathrm{HNMR}:\left(\mathrm{CDCl}_{3}\right) \delta=1.72\left(\mathrm{~s}, 6 \mathrm{H}, 2 \times \mathrm{CH}_{3}\right), 2.38\left(\mathrm{~s}, 1 \mathrm{H}, 3{ }^{\prime}-\mathrm{H}\right)$, 5.34 (brs, $2 \mathrm{H}, \mathrm{NH}_{2}$ ), 6.14 (brs, $\left.1 \mathrm{H}, \mathrm{NH}\right), 6.61$ (t, J=7.9 Hz, 1H, 5-H), 6.67 (d, J=8.0 Hz, 1H, 3-H), 7.18 (ddd, J=1.2, 7.1, 7.4 Hz, $1 \mathrm{H}, 4-\mathrm{H}), 7.77(\mathrm{dd}, \mathrm{J}=1.6,7.9 \mathrm{~Hz}, 6-\mathrm{H}) .{ }^{13} \mathrm{C} \mathrm{NMR}:\left(\mathrm{CDCl}_{3}\right) \delta=$ 
29.3, 47.9, 69.5, 87.6, 116.6, 116.8, 117.8, 127.6, 132.7, 149.3, 169.4. MS: $\mathrm{m} / \mathrm{z}=202\left[\mathrm{M}^{+}\right](55), 174(13), 136(20), 119(100)$, $105(30), 92(50), 65(42)$.

\section{2-Carbethoxyamino-N-(1,1-dimethylprop-2-ynyl)- benzamide 6}

To o-amino-N-(1,1-dimethylprop-2-ynyl)-benzamide $0.6 \mathrm{~g}$ $(0.3 \mathrm{mmol})$ and $0.034 \mathrm{~g}(0.4 \mathrm{mmol}) \mathrm{NaHCO}_{3}$ in $20 \mathrm{ml}$ dichloromethane was added at room temperature $0.033 \mathrm{~g}$ (0.3 mmol) ethyl chloroformate. The reaction temperature was then maintained at $40^{\circ} \mathrm{C}$ with stirring for 3 hours. $50 \mathrm{ml}$ of water was added and extraction carried out using $(3 \times 20$ $\mathrm{ml})$ dichloromethane. The combined organic phase was dried over anhydrous $\mathrm{Na}_{2} \mathrm{SO}_{4}$ and the removal of solvent in vacuo gave 6 which was recrystallised from methanol as colourless plates; $1.01 \mathrm{~g}(74 \%) ; \mathrm{mp}=182-183{ }^{\circ} \mathrm{C}$; IR
$(\mathrm{KBr}):=3360,3280(\mathrm{NH}), 2995(\mathrm{ArH}), 1710(\mathrm{C}=\mathrm{O}), 1640$ $(\mathrm{C}=\mathrm{O}), 1590(\mathrm{C}=\mathrm{O}), 1530,760 \mathrm{~cm}^{-1} .{ }^{1} \mathrm{HNMR}\left(\mathrm{DMSO}_{6}\right)$ : d $=1.32\left(\mathrm{t}, \mathrm{J}=7.1 \mathrm{~Hz}, 3 \mathrm{H}, \mathrm{OCH}_{2} \mathrm{CH}_{3}\right), 1.68\left(\mathrm{~s}, 6 \mathrm{H}, 2 \mathrm{xCH}_{3}\right), 2.61$ $\left(\mathrm{s}, 1 \mathrm{H}, 3^{1}-\mathrm{H}\right), 4.17\left(\mathrm{q}, \mathrm{J}=7.1 \mathrm{~Hz}, 2 \mathrm{H}, \mathrm{OCH}_{2} \mathrm{CH}_{3}\right), 7.0(\mathrm{t}, \mathrm{J}=$ 7.0Hz, 1H, 5-H), 7.43 (ddd, J = 1.0, 7.2, 7.7Hz, 1H, 4-H), 7.68 (dd, J = 1.5, 8.0Hz, 1H, 3-H), 8.24 (brs, $1 \mathrm{H}, \mathrm{N} \underline{\mathrm{H}}-\mathrm{COCH}_{2} \mathrm{CH}_{3}$ ), $8.29(\mathrm{~d}, \mathrm{~J}=8.6 \mathrm{~Hz}, 1 \mathrm{H}, 6-\mathrm{H}), 10.5$ (brs, $\left.1 \mathrm{H}, \mathrm{NH}\left(\mathrm{CH}_{3}\right)_{2}\right) .{ }^{13} \mathrm{C}$ NMR (DMSO-d $): \mathrm{d}=14.5\left(\mathrm{OCH}_{2} \underline{\mathrm{CH}}_{3}\right), 29.2\left(2 \mathrm{xCH}_{3}\right), 47.4$ $\left(\mathrm{C}-1^{1}\right), 60.8\left(\mathrm{OCH}_{2} \mathrm{CH}_{3}\right), 69.8\left(\mathrm{C}-3^{1}\right), 89.6\left(\mathrm{C}-2^{1}\right), 119.3(\mathrm{C}-3)$, 120.7 (C-1), 121.6 (C-5), 129.0 (C-6), $132.3(\mathrm{C}-4), 140.0$ (C-2), $153.8(\mathrm{Ph}-\underline{\mathrm{C}}=\mathrm{O}), 168.9\left(\mathrm{O}=\underline{\mathrm{C}}-\mathrm{OCH}_{2} \mathrm{CH}_{3}\right) . \mathrm{MS}: \mathrm{m} / \mathrm{z}(\%)=274$ (7) $\left[\mathrm{M}^{+}\right], 259$ (2), $228(4), 202(20), 162$ (16), 146 (100), 119 (52), 90 (18), 65 (60), 41 (75); Elemental Analysis: $\mathrm{C}_{15} \mathrm{H}_{18} \mathrm{~N}_{2} \mathrm{O}_{3}$; Calculated: C, 65.44 H, 6.91 N, 10.18; Found : C, 65.24 H, 6.61 N, 10.22.

\section{SCHEME}<smiles>C#CC(C)(C)N</smiles><smiles>C#CC(C)(C)NC(=O)c1ccccc1N</smiles>

3<smiles>C#CC(C)(C)NC(=O)c1ccccc1NC(C)=O</smiles>

4<smiles>C#CC(C)(C)NC(=O)c1ccccc1NC(=O)OCC</smiles><smiles>C=C1OC(c2ccccc2NC=O)N=C1C</smiles>

6<smiles>C#CC(C)(C)n1c(=O)[nH]c2ccccc2c1=O</smiles>

8

i: DMF, $50^{\circ} \mathrm{C}$

ii: Ethylchloroformate, $\mathrm{CH}_{2} \mathrm{Cl}_{2}, \mathrm{RT}$

iii: $\mathrm{KOH} /$ ethanol, reflux

iv: Triethylorthoformate, Acetic anhydride, reflux 
Reactions of o-Amino-N-(1,1-dimethylprop-2-ynyl)-benzamide.

2-(o-Carboethoxyaminophenyl)-4,4-dimethyl-5methylene-4H-oxazole 7

$\mathrm{KOH} 0.18 \mathrm{~g}(0.3 \mathrm{mmol})$ was added to 2-carbethoxy-amino$\mathrm{N}$-(1,1-dimethylprop-2-ynyl)-benzamide $0.5 \mathrm{~g}(0.2 \mathrm{mmol})$ in $15 \mathrm{ml}$ ethanol. The mixture was stirred and gently heated to reflux and maintained at reflux for 3 hours afterwhich it was cooled, adjusted to $\mathrm{pH} 7$ with acetic acid and extracted with chloroform. The organic layer was dried over anhydrous $\mathrm{Na}_{2} \mathrm{SO}_{4}$ and the solvent removed in vacuo to give a yellow oil; $0.375 \mathrm{~g}(75 \%)$; IR: $(\mathrm{NaCl})=3250(\mathrm{NH})$, $2900(\mathrm{ArH}), 1710\left(\mathrm{C}=\mathrm{CH}_{2}\right), 1695(\mathrm{C}=\mathrm{O}), 1640,1600,1590$, 1240, 850, $760 \mathrm{~cm}^{-1}$; ${ }^{1} \mathrm{H} \mathrm{NMR}\left(\mathrm{CDCl}_{3}\right): \mathrm{d}=1.33(\mathrm{t}, \mathrm{J}=7.1 \mathrm{~Hz}$, $\left.3 \mathrm{H}, \mathrm{OCH}_{2} \mathrm{CH}_{3}\right), 1.48\left(\mathrm{~s}, 6 \mathrm{H}, 2 \mathrm{xCH}_{3}\right),(\mathrm{q}, \mathrm{J}=7.1 \mathrm{~Hz}, 2 \mathrm{H}$, $\left.\mathrm{OCH}_{2} \mathrm{CH}_{3}\right), 4.27(\mathrm{~d}, \mathrm{~J}=3.0 \mathrm{~Hz}, 1 \mathrm{H},=\mathrm{CH}$ trans $), 4.76(\mathrm{~d}, \mathrm{~J}=$ $3.0 \mathrm{~Hz}, 1 \mathrm{H},=\mathrm{CH}$ cis), 7.05 (ddd, J=1.1, 7.3, 7.4, Hz, 1H, 5-H), 7.48 (ddd, $\mathrm{J}=1.7,7.3,8.6, \mathrm{~Hz}, 1 \mathrm{H}, 4-\mathrm{H}$ ), 7.88 (dd, J=1.7, 8.0 $\mathrm{Hz}, 1 \mathrm{H}, 3-\mathrm{H}), 8.48$ (d, J = 8.5Hz, 1H, 6-H), 11.35 (brs, 1H, $\mathrm{NH}) ;{ }^{13} \mathrm{C} \mathrm{NMR}\left(\mathrm{CDCl}_{3}\right): \mathrm{d}=14.7\left(\mathrm{OCH}_{2} \mathrm{CH}_{3}\right), 30.0\left(2 \mathrm{xCH}_{3}\right)$, $61.2\left(\mathrm{OCH}_{2} \mathrm{CH}_{3}\right), 69.6(\mathrm{C}-4), 82.9\left(\mathrm{C}_{-} \mathrm{CH}_{2}\right), 112.2\left(\mathrm{C}-1^{1}\right), 118.8$ $\left(\mathrm{C}-3^{1}\right), 121.7\left(\mathrm{C}-5^{1}\right), 129.6\left(\mathrm{C}-6^{1}\right), 133.2\left(\mathrm{C}-4^{1}\right), 141.0\left(\mathrm{C}-2^{1}\right)$, $154.5(\mathrm{C}-5), 160.2(\mathrm{C}-2), 166.6(\mathrm{C}=\mathrm{O}) ; \mathrm{MS}: \mathrm{m} / \mathrm{z}(\%)=274$ (28) $\left[\mathrm{M}^{+}\right], 259$ (7), 231 (16), 203 (12), 163 (22), 145 (100), 118 (96), 90 (68), 77 (22); High resolution MS: for $\mathrm{C}_{15} \mathrm{H}_{18} \mathrm{~N}_{2} \mathrm{O}_{3}$ : Calculated: 274.1302; Found: 274.1317; Elemental Analysis: $\mathrm{C}_{15} \mathrm{H}_{18} \mathrm{~N}_{2} \mathrm{O}_{3}$ Calculated : C, 65.71 H, 6.57 N, 10.22; Found : C, $65.66 \mathrm{H}, 6.51 \mathrm{~N}, 10.09$.

\section{2-Acetylamino-N-(1,1-dimethylprop-2-ynyl)-benzamide 4}

The condensation of o-amino-N-(1,1-dimethylprop-2ynyl)-benzamide $\quad \begin{array}{llllll}3 & 1.0 & \mathrm{~g} & (0.005 & \mathrm{mol}) & \text { with }\end{array}$ triethylorthofomate $1.10 \mathrm{ml}(0.006 \mathrm{~mol})$ in acetic anhydride (10 ml) after 3 hrs gave a crude product which on column chromatography yielded 2-acetylamino-N-(1,1dimethylprop-2-ynyl)-benzamide $\mathbf{4}$ as colourless needles from dichloromethane/hexane; $0.98 \mathrm{~g}(80 \%) ; \mathrm{mp}=140-142$ ${ }^{\circ} \mathrm{C}$; IR (KBr): = 3360, $3280(\mathrm{NH}), 2995(\mathrm{ArH}), 1710(\mathrm{C}=\mathrm{O})$, $1640(\mathrm{C}=\mathrm{O}), 1530,760 \mathrm{~cm}^{-1} .{ }^{1} \mathrm{H} \mathrm{NMR}\left(\mathrm{CDCl}_{3}\right): \mathrm{d}=1.77(\mathrm{~s}$, $\left.6 \mathrm{H}, 2 \mathrm{xCH}_{3}\right), 2.16\left(\mathrm{~s}, 3 \mathrm{H},-\mathrm{COCH}_{3}\right), 2.44(\mathrm{~s}, 1 \mathrm{H},=\mathrm{CH}), 6.59$ (brs, 1H, NH), 6.99-7.07 (ddd, J = 1.9, 7.128.0Hz, 1H, Ar-H), 7.28-7.49 (m, 2H, Ar-H), 8.49-8.50 (dd, J = 1.5, 8.0Hz, 1H, Ar$\mathrm{H}), 10.87$ (brs, $1 \mathrm{H}, \mathrm{NH}) .{ }^{13} \mathrm{C} \mathrm{NMR}\left(\mathrm{CDCl}_{3}\right): \mathrm{d}=25.4,29.2$, 48.3,69.9, 86.9, 121.2, 121.9, 122.9, 127.1,132.9, 139.9, 168.9, 169.6. MS: $\mathrm{m} / \mathrm{z}(\%)=244(30)\left[\mathrm{M}^{+}\right], 202(38), 162(36), 136$ (32), 119 (100), 92 (60), 82 (26), 65 (52); Elemental Analysis: $\mathrm{C}_{14} \mathrm{H}_{16} \mathrm{~N}_{2} \mathrm{O}_{2}$; Calculated: $\mathrm{C}, 68.83 \mathrm{H}, 6.60 \mathrm{~N}, 11.47$; Found : C, 68.70H, 6.50 N, 11.42.

\section{DISCUSSION}

Quinazolinone can be synthesised by carbonylation of Nsubstituted anthranilamide with ethylchloroformate and subsequent cyclization under basic conditions ${ }^{2}$. Attempted cyclization of $\mathbf{6}$ to the quinazolinone $\mathbf{8}$ was carried out using ethanolic potassium hydroxide and the oxazole 7 formed was as a result of angular cyclization of the side chain. It has however been reported that under basic conditions, the side chain rearranges to the respective oxazole ${ }^{4}$. This shows that angular cyclization is favoured to the elimination of the ethoxy group which should have led to the formation of the expected quinazolinone 8 . When 6 was refluxed in high boiling solvents like chlorobenzene, the oxazole was obtained in lower yield. Cyclocondensation reaction of $\mathbf{3}$ using the appropriate orthoester in the presence of acetic anhydride gave mainly $\mathrm{N}$-acetylated product 4 and negligible yields of envisaged 3propynylqunazolinone $\mathbf{5}$. The product obtained was different from that earlier reported ${ }^{7}$ in which the orthoesters were refluxed in ethanol and equimolar amount of glacial acetic acid, the major product obtained was 3propynylqunazolinone $\mathbf{5}$. The compounds were characterised by their spectroscopic data and elemental analysis.

Compound $\mathbf{6}$ was essentially spectroscopically similar to compound $\mathbf{5}$ except for the carbethoxy group which was clearly shown in the ${ }^{1} \mathrm{HNMR}$ as a triplet and quartet. A broad siglet at $8.24 \mathrm{ppm}$ also confirm the presence of $\mathrm{NH}$ of the carbethoxy amine group. Attempted cyclization of 6 to $\mathbf{8}$ was not possible rather the oxazole 7 was obtainted. The mass spectra clearly confirmed the formatoin of the oxazole 7. The presence of two doublet ( $\left.{ }^{1} \mathrm{HNMR}\right)$ between 4 and $5 \mathrm{ppm}$ attributable to the exocyclic methylene proton (cis and trans) in addition to the presence of the carbethoxy moiety support the oxazole structure.

\section{ACKNOWLEDGEMENT}

The authors wish to thank Pharmaceutical Chemistry Department, University of Münster, Germany for the assistance in running some of the spectra.

\section{REFERENCES}

Farghaly, A. M., Chaaban, I., Khalil, M. A. and Behkit, A. A. (1990) Non-Steriodal Antiimflammatory Agents II: Synthesis of Novel Pyrazole and Pyrazoline Derivatives of 4-(3H)-Quinazolinone. Arch. Pharm. (Weinheim) 323, 311-315.

Gadekar, S. M., Kotsen, A. M. and Cohen, E. (1964) Anthranilamides as Intermediates for 3-Substituted Quinazoline-2,4-diones. J. Chem. Soc. 4666-4668. 
Johne, S. (1982) Progress in Drug Research. In: Search for Pharmaceutically interesting Quinazoline Derivatives: Efforts and Results (1969-1980), ed. Jucker E. Birkhäuser Verlag, Stuttgart vol 26, pp 259-341.

Nilsson, B. M. and Hacksell, U. (1989) Base-catalyzed Cyclization of N-Propargylamides to Oxazoles. J. Heterocyclic Chem. 26 269-275.

Reisch, J., Usifoh, C. O. and Oluwadiya, J. O. (1989) Synthesis of Oxazoles and Oxazoloquinazolines from o-Amino-N-(1,1-disubstituted-propynyl)-benzamide. J. Heterocyclic Chem. 26, 1495-1498.

Reisch, J., Usifoh, C. O. and Oluwadiya, J. O. (1992) Ring Opening of 3-Azaisatoic anhydride with Acetylenic amines: Synthesis of Pyrido-(2,3-d)-pyridmidinones. Monatsh. Chem. 123, 247-250.

Reisch, J., Usifoh, C. O. and Oluwadiya, J. O. (1990) Acetylenic amides as Precursors for the Synthesis of 3-Propynylqunazolinones. J. Heterocyclic Chem. 27, 1953-1956.

G. M. Coppola (1982) The Chemistry of Isatoic Anhydride, Synthesis 505-535.

Clark C. R and Davenport T.W . (1987) Synthesis and anticonvulsant activity of analogues of 4-Amino-N(1-phenylethyl)-benzamide. J. Med. Chem. 30, 12141217

Usifoh, C. O. and Scriba G.K.E (2000) Synthesis and Anticonvulsant activity of Acetylenic Quinazolinone derivatives. Arch. Pharm. Pharm. Med. Chem. 333, 261-266. 